\title{
Shared Principles of Restoration Practice in the Chicago Wilderness Region
}

Cristy Watkins

University of Michigan, Ann Arbor, Michigan, United States

Lynne M. Westphal ${ }^{1}$

USDA Forest Service, Evanston, Illinois, United States

Paul H. Gobster

USDA Forest Service, Evanston, Illinois, United States

Joanne Vining

University of Illinois, Urbana, Illinois, United States

Alaka Wali

The Field Museum, Chicago, Illinois, United States

Madeleine Tudor

The Field Museum, Chicago, Illinois, United States

\section{Abstract}

We describe the rules, norms, and strategies (institutional statements) that characterize ecological restoration across 10 organizations in the Chicago Wilderness region. Our use of Ostrom's IAD ADICO grammar tool is novel in both context (non-extractive resource management) and data type (qualitative interviews). Results suggest that, in contrast to a focus on rules in the literature, restoration is overwhelmingly guided by strategies (institutional statements void of tangible or emotional sanctions). Moreover, a small, but critical set of norms exist. From over 1,700 institutional statements extracted, we found a suite of rich principles that guide behavior in all of the organizations: (1) qualify, don't quantify; (2) listen to the land; (3) practice follow-up; (4) do no harm; (5) respond to sanctions from the land; (6) balance diverse internal stakeholders; and (7) balance diverse external factors. These principles suggest that Chicago Wilderness restorationists have a strong shared understanding upon which collective action and adaptive management occurs.

1 Corresponding author: lwestphal@fs.fed.us 
Keywords: ADICO, Chicago Wilderness, ecological restoration, institutional statements

\section{Introduction}

Ecological restoration is "[t]he process of assisting the recovery of damaged, degraded, or destroyed ecosystems" (SER, 2004, p. 1). Restoration, as an approach to ecosystem management, involves setting goals that are guided by scientific knowledge and societal values; it is a human-implemented procedure, and people perceive and interpret ecosystems - what they are and what they should be - in different ways (Glaser, 2006; Manuel-Navarrete et al., 2004). In comparison to many other land management activities (e.g., fishing, timber harvesting) ecological restoration is relatively new and has a different purpose. Restoration emerged in the United States within the last century, but has evolved into academic and professional pursuits only within the last several decades (Ehrenfeld, 2000; Jordan \& Lubick, 2011). Ecological restoration adds value to an ecosystem, and is often, although not exclusively, practiced where resource extraction is not a goal. Restoration goals may include the protection and enhancement of ecosystem services, provision of social and spiritual benefits, and protection of specific species.

Ecological restoration constitutes a social-ecological systems "problem" (Ostrom, 2007). That is, ecological restoration is typically a collective action situation in which multiple individuals all benefit from a particular action (e.g., restoring ecosystem services), but in order to reap these benefits some individuals must work together and share the costs. ${ }^{2}$ Costs can include budget issues, information needs, coordination limitations, competing priorities, and political conflicts - all of which could lead to uncooperative behavior (Imperial, 1999). Furthermore, even when there are accepted goals and techniques (e.g., prescribed fire, invasive species control), the ways or extent to which these techniques are used, or even expectations of what exactly the outcomes might look like, can differ (Gobster \& Hull, 2000).

Ecological restoration is most likely to be successful when there is (1) cooperation between individuals, (2) a willingness to learn, and change both perceptions and actions, and (3) the integration of both environmental and social considerations (Imperial, 1999; Long et al., 2003; Pahl-Wostl, 2006; Smith, 2013). As a cooperative endeavor that supports a mutually beneficial relationship between humans and the landscape, ecological restoration can be enhanced by institutions that guide individual and collective behavior. Institutions are

2 While restoration activities can and do take place on privately owned land by the single landowner, in this paper we focus on ecological restoration taking place on public lands, or on lands held by land trusts. These situations constitute collective action situations. 
rules, norms, and strategies, or collectively shared prescriptions, that guide behavior (Ostrom, 2005). The analysis of institutions, as the social tools that influence behavior trade-offs, is a distinct and important type of inquiry that can help link social and ecological phenomena and, in particular, advance our understanding of sustainable ecosystem management (Mincey et al., 2013). Even where maximizing extractive potential is not a goal, properly designed institutions can increase stability and reduce uncertainty (Ostrom, 2007).

We describe here the institutions that guide urban ecological restoration in the Chicago Wilderness region. We use the ADICO grammar tool (Crawford \& Ostrom, 2005) to extract the institutional statements from a set of in-depth interviews of restorationists. ADICO (Attribute, Deontic, aIm, Condition, and Or else) allows for the systematic formatting of rules, norms, and strategies that frequently are only tacitly understood. In contrast to much of the institutional literature, we give equal attention to all three types of institutional statements. We then extend our focus to the suite of institutional statements that broadly characterize a shared suite of philosophical principles followed by Chicago Wilderness restorationists. These principles highlight ecological restoration as a non-extractive natural resource management practice guided by a sense of responsibility to and a connection with the land. First we provide a brief history of the practice of ecological restoration, and particularly its evolution in the Chicago metropolitan region, as well as previous applications of institutional analyses and ADICO.

\section{Background}

\section{Ecological restoration in Chicago Wilderness}

Chicago Wilderness is "a regional biodiversity conservation alliance committed to protecting nature and enriching the lives of the region's residents" (Heneghan et al., 2012, p. 74). The alliance serves as a source and coordinator of information (and often financial and other support) for more than 360 member organizations, which include government agencies, large and small conservation organizations, cultural and education institutions, volunteer groups, corporations, and faithbased groups. Many of Chicago Wilderness' members conduct ecological restoration within the region's 360,000 acres of protected natural areas. As outlined in the 1999 Biodiversity Recovery Plan, Chicago Wilderness members share broad, common goals that are based in restoration ecology science (CRBC, 1999). However, activities and plans developed to implement these goals vary among Chicago Wilderness land managing organizations.

The RESTORE (rethinking ecological and social theories of restoration ecology) project explores whether and how decision-making styles affect biodiversity 
outcomes in a range of Chicago Wilderness organizations. Funded by the National Science Foundation's Dynamics of Coupled Natural and Human Systems program, the RESTORE project focuses on groups in Chicago Wilderness who collectively make decisions regarding oak woodland restoration projects. RESTORE has this focus because (1) oak ecosystems are in decline and are of global conservation significance (Knoot et al., 2010), and (2) restoration techniques can be especially contentious because differences in positions on land use and management practices exist at the human/nature interface (e.g., Crane et al., 2014; Gobster \& Hull, 2000).

The project explores distinct management categories: manager-led, comanagement, and research-led. Manager-led describes projects in which the landowner is dominant in decision-making and on-the-ground management; co-management describes projects in which there is a high degree of volunteer participation and autonomy in both decision-making and on-the-ground activities, and the landowner may or may not be active in decision-making and management; and finally, research-led describes projects in which scientific exploration is central to restoration activities. The RESTORE project investigators sought to describe, compare, and contrast these decision-making styles using a variety of analytic tools, including agent-based modeling (Watkins et al., 2013; Zellner et al., 2014), thematic content analysis (themes such as conflict, communication, emotions), and the extraction of rules, norms, and strategies, as framed in the institutional analysis and development literature (Ostrom, 2005).

Chicago Wilderness has been lauded for its role in "the development of a new code of ethics for biodiversity conservation" (Mackey et al., 2008, p. 1). In particular, an IUCN case study of the Chicago Wilderness alliance, which documented the alliance's "practical solutions, ethical values and principles that underpin [its] work" (Mackey et al., 2008, p. 4), informed a global biodiversity conservation plan that stresses human responsibility, a moral obligation to change, and the importance of economic and social justice.

Chicago Wilderness's approach complements the philosophical arguments of several restoration ecology scholars who argue that the practice of restoration is personal, perceptual, and experiential, and that there are limits to how much one can, and should, define restoration goals (Ehrenfeld, 2000; Hobbs, 2007; Simpson, 2009). Higgs (2005) maintains that while scientific information is critical to restoration, the practice must respect and integrate other kinds of knowledge and even "a moral center that is beyond the scope of science" (p. 159). Indeed, ecological restoration is a form of adaptive management through which knowledge is gained incrementally through on-the-ground practices and, often, the sharing of information between restorationists. A recent review of restoration projects found that the goals were much broader than those acknowledged in the Society for Ecological Restoration's "attributes 
of restoration," which primarily consider form, function, and stability of an ecosystem; over half of the projects had broader goals related to social needs, such as cultural values and community engagement (Hallett et al., 2013). All this is to say, ecological restoration is fundamentally a social-ecological practice guided by both scientific knowledge as well as broader social understandings of human-environment interaction.

\section{Institutional analysis and the ADICO tool}

Institutions (rules, norms, and strategies) are the human-created prescriptions designed to affect incentives and guide behavior (McGinnis, 2011; Ostrom, 2005, 2011). Rules, norms, and strategies are differentiated in part by the sanction associated with following or not following the prescription. A rule has a tangible sanction (e.g., a reward or a fine and a system for monitoring infraction), a norm has an emotional sanction (e.g., pride or guilt) and a strategy lacks tangible or emotional sanctions (Ostrom, 2005; Schlüter \& Theesfeld, 2010). ${ }^{3}$ However, Schlüter and Theesfeld (2010) suggest that strategies often have automatic sanctions, that is, sanctions not imposed by another person (e.g., getting in an accident from driving on the wrong side of the road).

Institutional analyses have been used to understand the conditions under which successful resource management institutions are most likely to emerge, primarily in developing country contexts where livelihoods are based on resource extraction (e.g., Chhatre \& Agrawal, 2008; Gibson et al., 2000). The existence of rules, and in particular the prevalence and effectiveness of monitoring and tangible sanctioning in successfully managing extractive common-pool natural resource situations, is the focus of most institutional analyses to date (Coleman \& Steed, 2009; Gibson et al., 2005; Madrigal-Ballestero et al., 2013; Ostrom, 1990). Institutional analyses of non-extractive resource management in selforganized rural communities in Indiana have also been conducted (Fleischman et al., 2010; Gibson \& Koontz, 1998; Mincey et al., 2013). These studies suggest that the most effective and robust institutions are those that support collective values through social learning and interaction, implying that norms may also be important (although norms were not explicitly studied).

Institutional analyses to date have made clear the types and importance of rules, but little to no attention has been paid to the type, distribution, and impact of norms and strategies. Nonetheless, the theoretical basis has been laid by Ostrom and colleagues (Crawford \& Ostrom, 1995, 2005; Ostrom 2005). To reveal, differentiate between, and systematically analyze rules, norms, and strategies,

3 Rules, norms, and strategies can function at multiple, but linked, levels of analysis (operational, collective choice, and constitutional). There is also a set of institutional statement classifications, including position statements, boundary statements, and more. Because this paper focuses on the type of statements (rules, norms, and strategies) used by Chicago Wilderness restorationists, we forego detail on the other components. 
Crawford and Ostrom (2005) developed the ADICO grammar tool (Table 1). Understanding whether a component is present is critical to determining whether it is a rule, norm, or strategy. A rule contains all five components (ADICO). A norm contains all but an "or else" (ADIC). A strategy contains all but a deontic and an "or else" (AIC). We use work by Schlüter and Theesfeld (2010) to further distinguish and track the sanctions associated with norms and strategies, since neither is captured by the "or else" component of the ADICO syntax, although they are acknowledged in institutional analyses (Ostrom, 2005).

Table 1. The components of the ADICO syntax and how they define rules, norms, and strategies

\begin{tabular}{|c|c|}
\hline Component & Definition \\
\hline A & Attribute (the "who": who does this statement refer to?) \\
\hline $\mathrm{D}$ & Deontic (may, must, must not, should, should not) \\
\hline I & alm (the "what": what is the statement about?) \\
\hline $\mathrm{C}$ & $\begin{array}{l}\text { Condition (under what conditions must the aim occur?) } \\
\text { * Default can be "in all times and in all places" (Ostrom, 2005, p. 149) } \\
\text { or "everywhere and always" }\end{array}$ \\
\hline O & $\begin{array}{l}\text { Or else (the tangible sanction for not following a rule) } \\
\text { * The term "or else" is used only for rules } \\
\text { * Can be gradual: Initial or accidental violations may not incur tangible } \\
\text { sanctions, but repeated violations lead to them }\end{array}$ \\
\hline & $\mathrm{ADICO}=$ rule, $\mathrm{ADIC}=$ norm, $\mathrm{AIC}=$ strategy \\
\hline
\end{tabular}

Source: Ostrom (2005).

To date, ADICO has been applied only to state-level written policy (Basurto et al., 2010; Siddiki et al., 2011). To our knowledge, our study was the first application to a non-extractive resource management situation and in which the primary data are qualitative interviews and participant observation. Our goal in using ADICO was to identify the individual rules, norms, and strategies that guide the organizations' decision-making processes, actions, and outcomes. To understand whether it was appropriate to focus mainly on rules (that is, institutional statements with tangible sanctions), we tracked the prevalence and strength of all three types of institutional statement. We acknowledge that the ADICO grammar tool is just one way to understand the decision-making process, and as such can complement other forms of analysis (e.g., content analysis). Thus, in this paper we also rely heavily on our qualitative data to evaluate and inform the meaning, strength, and relevance of each institutional statement, or sets of statements. 


\section{Methods}

\section{Case study}

Ten Chicago Wilderness member organizations of various types, sizes, and geographic locale participated in this study and each represented one of our three a priori management categories. Four organizations were manager-led (M1, M2, M3 and M4), four were co-management (C1, C2, C3, and their comanaging landowner, and $\mathrm{C} 4$, whose associated landowner was not active in management), and two were research-led (R1 and R2). We conducted over 80 semi-structured, confidential interviews with restoration decision makers and over 50 observations of organization meetings and ecological restoration workdays between March 2010 and December 2012 (details of these methods can be found in Westphal et al., 2014). The interviews were extensive and covered topics such as background and job responsibilities, respondent's assessment of the natural area in question, restoration decision-making processes in their organization, and the importance and inclusion of the public and resources such as money and labor in decision-making. Interviews were recorded and transcribed for analysis. Field notes from participant observation sessions were written within 24 hours of the fieldwork (Westphal et al., 2014).

\section{Content analysis and institutional statement extraction}

As our analytical process using the ADICO syntax is detailed in great length in (Westphal et al., 2014), we only briefly describe it here. After interviews were transcribed verbatim, they were analyzed for broad themes, including but not limited to management actions, decision information, perceptions of landscape, and emotion. This analysis gave us a deep understanding of the data and the thematic patterns therein before we identified each rule, strategy, and norm. We then analyzed the statements in the context of the full data set, and relied on all that we had learned about the organizations through the thematic content analysis. For all institutional statements and ethnographic data, we provide the case ID code (e.g., M2 or R1) and a pseudonym for the respondent.

\section{Results}

We extracted 1,747 institutional statements from our interview data. About two-thirds of the institutional statements are strategies. Given the focus on rules in most institutional analysis and development studies, and given that they are not the most dominant type of institutional statement in our study, it is worth noting the kinds of rules we did extract. Rules were primarily about acquiring 
approval (from bosses or boards, or from agencies for permits), abiding by restrictions of grants and referenda, spending money, and public use of sites. For example, two rules found in every organization were:

- $\quad$ restorationists must be trained and certified to operate a chainsaw;

- $\quad$ restorationists must apply for a permit to apply herbicide.

Few rules described on-the-ground application of a particular restoration technique. One exception is the following rule, also found in every organization: restorationists must not "smoke out" neighbors (during a prescribed burn). Failure to abide by any of these rules could result in tangible sanctions such as fines and revoked privileges.

\section{Restoration principles}

We found several sets of recurring statements that thematically describe and guide ecological restoration as a practice in the Chicago Wilderness region. We aggregated institutional statements that exhibited a common theme as a "principle." Norms and strategies, as well as rules, played an important role in these principles. While not every interviewee expressed the principles, all principles were found in every study organization. Next we describe these seven ecological restoration principles in detail, giving several examples of the kinds of institutional statements from which the principles were composed. We also provide qualitative data excerpts from which the institutional statements were extracted.

\section{Qualify, don't quantify}

In comparison to other natural resource management contexts in which institutional analysis has been conducted, we found very few statements that quantify the inputs or outputs of behavior (e.g., number of trees harvested, number of pounds of fish caught).

Institutional statements in which actions were quantified allowed us to see where there was variation in implementation of particular restoration practices. For example, the multiple institutional statements concerning the quantification of seeding practices (examples C, D, and E in Table 2), led us to confirm that seeding practices are more varied across organizations than other basic restoration actions, such as prescribed burns, removal of invasive species, or deer management. 
Table 2. Examples of institutional statements that specified a quantified input or output, that is, a numerical upper or lower bounds for particular restoration actions

\begin{tabular}{|c|c|}
\hline Restoration action & Example of institutional statement \\
\hline $\begin{array}{l}\text { (A) Size of stem that volunteers } \\
\text { are able to cut }\end{array}$ & $\begin{array}{l}\text { Volunteers must not cut stems that are larger than } 6 \\
\text { inches in diameter, always and everywhere, or else risk } \\
\text { losing volunteer privileges [Rule] }\end{array}$ \\
\hline $\begin{array}{l}\text { (B) Frequency and extent of } \\
\text { conducting prescribed burns }\end{array}$ & $\begin{array}{l}\text { Restorationists burn biennially, such that } 50 \text { percent } \\
\text { of parcel is done annually, when and where possible } \\
\text { [Strategy] }\end{array}$ \\
\hline $\begin{array}{l}\text { (C) The distance within which } \\
\text { seeds can be purchased and/ } \\
\text { or collected }\end{array}$ & $\begin{array}{l}\text { Restorationists must only purchase seed that has been } \\
\text { harvested from within } 100 \text { miles of purchase location, } \\
\text { always and everywhere, or else risk losing job [Rule] }\end{array}$ \\
\hline $\begin{array}{l}\text { (D) The amount of seeds that } \\
\text { can be collected from a } \\
\text { given population }\end{array}$ & $\begin{array}{l}\text { Restorationists collect two-thirds of seed population, } \\
\text { always and everywhere [Strategy] }\end{array}$ \\
\hline (E) When to sow in seeds & $\begin{array}{l}\text { Restorationists avoid seeding after the first year } \\
\text { of buckthorn seedlings and re-sprouts always and } \\
\text { everywhere [Strategy] }\end{array}$ \\
\hline
\end{tabular}

We found an abundance of strategies (institutional statements with no tangible or emotional sanction) that describe specific inputs of restoration practices qualitatively and in relative terms. Often, these statements read like a restoration field handbook or suggested guidelines, rather than explicit, quantified actions. For example, consider the following interview excerpts and the strategies we extracted from them:

(1) Kent [will] see if there's a patch of loosestrife this year in the wet area, then he's gotta make that his priority to get that before it goes to seed and drops ... So there's a certain schedule with seasonal, how seasons go, and it's up to us to prioritize. (Susan, M3)

Restorationists get to invasive plants before "it goes to seed and drops," when and where possible.

(2) And, for instance, somebody came in and they really didn't want us cutting down cherry trees ... They are not very fire resistant and they just didn't live in the habitats that we were restoring. Historically. We're trying to restore things from the plant community up. (Roger, C3)

Restorationists remove cherry trees, when and where appropriate.

(3) [I'd focus more on] just cutting buckthorn out there - doing anything out there! Any clearing that we do in the woods, generally we don't clear more land than we have seed to sow. (Jen, Rl)

Restorationists clear buckthorn, only if they have sufficient seed to sow after removal. 
Restorationists often stated or implied that if they were successful in their work they would feel pride and other positive emotions, indicating that with lack of success they would likely experience emotions like guilt and shame. For example, consider the following interview excerpts and the norms we extracted from them:

(1) Interviewer: What [is] the overall goal for the management of the woodlands?

Bob: To sustain and conserve natural resources; to promote diverse, healthy, natural, thriving, functional ecosystems ... I'm saying that with smirk-because it sounds generic - but I really do believe it. (Bob, R2)

[Organization] must sustain and conserve natural resources, promote diverse, healthy, natural, thriving, functional ecosystems, always and everywhere (norm).

(2) Some people like to clear all the crap out and start throwing seed everywhere. Well, our attitude has always been, you know, the [native] seed bank is there. It's got a lot of stuff in it that hasn't been able to express itself because it's been covered over with buckthorn or whatever else. Let's see what's already there before we start changing things ... Because I think an attitude that they [volunteers] have and a lot of people have is that they want to see something change within their lifetime ... as much as we like to see, you know, all the crap gone, all the trillium pops up, everything's great ... That may not be realistic. (Jerry, Cl-3)

Restorationists should wait to see what is in the seedbank before seeding, always and everywhere (norm).

The first data excerpt and norm illustrate Bob's expressed deep belief in a broad, organizational goal that, when attempted, brings pride. In the second excerpt, Jerry concedes that there may be a desire to see immediate changes, but stresses that there is a responsibility to be realistic and patient. Jerry illustrates a concern that some restorationists might act too fast and therefore potentially waste resources and, even worse, miss what was waiting to express itself from the seed bank. Interestingly, in the same way that quantification of whether and when in a restoration project to sow seed was diverse across organizations, this kind of norm was not unanimous across, or even within, all organizations. Other groups had norms that strongly suggested the need for seeding because there is no dormant seedbank, and in several organizations there were disagreements about whether or how long to wait. Both versions of the wait/don't wait seeding norm are indicative of the qualitative principle because both lack a specific quantification of how soon to seed or how long to wait. 


\section{Listen to the land}

One principle that was ubiquitous across all cases was the importance and power of connecting with, observation of, and listening to the landscape, along with the ability to adapt. This principle consisted of a mix of norms and strategies. For example, consider the following interview excerpts:

(1) We meet this great guy ... who is just a restoration and ecology genius of a person ... he goes "have you ever slept out on the prairie? It will tell you what it needs." I thought it was such a kooky answer - that's why I think I like him so much-he's a little wacky like that but I think what he is just trying to tell me is, don't worry about all the technology and just do what you really think is going to work well and work from your heart. (Becky, M4)

Restorationists should do what they really think is going to work well and work from their heart, always and everywhere (norm).

(2) ... he's spent literally thousands of hours, 25 years, learning all this stuff. He couldn't possibly write it so that someone else would know. I imagine like what tribal people used to be. He knows when certain plants are ... when their seeds are ripe. Now if you did a written plan and said "well, bud root seed is going to be ripe on May 1st." but if it's been a cold spring it won't be ripe on May 1st. It might be ripe on May 12th. Al knows that. He'll keep track. He's like one of those old shamans that they had in the tribal society that knows. He'll see the signs. (Doug, C4)

Restorationists make decisions based on day-to-day observations and advice from others, and not the calendar date (strategy).

In the first excerpt, a land manager describes a successful seeding dispersal project and seeding advice given to her by a fellow restorationist. The references to "working from your heart" and "just think how nature does it" indicate the presence, and application, of emotion as derived from a connection to the land, to guide restoration decisions. The references to "tribal knowledge" and experience in excerpt two indicate the importance of paying attention to the land and using direct observations and intuition to inform decisions. The ability to be able to listen to the land was present in every organization, although not every individual mentioned it. Indeed, as the excerpts above suggest, some individuals are particularly lauded and sought out for their ability to listen to the land. 


\section{Practice "follow-up"}

Another guiding restoration principle is ensuring that "follow-up" is possible. Follow-up means returning to an area to ensure that restoration actions are having a positive impact and conducting the same action again or applying a secondary one (e.g., applying herbicide to recently cut stems of invasive plants) as needed. This was an important principle in every organization. Here we provide two excerpts and their extracted strategies:

(1) Related to invasive species control ... It's being persistent and repeating and going back multiple years to actually make headway. Being very diligent. I would say that that's a rule of thumb ... We know that as much as we try to implement an ... effective prescribed burn regime at a particular site or within a particular community, that that will not always take care of the woody invasive species. And that we have to go back and pay attention to those small stems. (Lori, M2)

[The organization] conducts follow-up management actions, always and everywhere.

(2) They [the operations field staff] have a lot of areas that they've been working on year after year, and they still are going into those areas ... I could come up with a lot more sites for them, [but] we gotta realistically think: What sites can they get to? Don't want to have them clear all brand new areas that we haven't even touched yet ... So, they're going to continue working on some of these areas 'til they feel that they're restored and that they could let them go naturally. (Mitch, M1)

Ecologists do not suggest new sites to work on if crews can't keep up and older sites aren't functioning "naturally."

\section{Do no harm}

Yet another pervasive principle for conducting restoration is a "do no harm" philosophy. Like listening to the land and follow-up, this principle is exemplified by a mix of institutional statement types. Consider the following interview excerpts and their associated institutional statements:

(1) If we're doing winter work, we need to get off into a sensitive area, get equipment off the road ... we would need to have frozen grounds so that we can get equipment off without causing damage to soil, for example. So we don't wanna just drive off the roads and cause these paths and ruts and this kind of thing. (Bob, R2)

Restorationists use equipment on sensitive areas only in the winter when ground is frozen (strategy). 
(2) It's just that the [organization] wants to promote volunteership from the corporate groups, but it's sort of like getting people to use the woods by creating a trail system. A lot of people here don't appreciate if you have 30 people come into the woods in the spring when it's soft and muddy and wet and the ephemerals are blooming. You don't want 30 people marching around, pulling garlic mustard or doing whatever. Or cutting buckthorn in the middle of the summertime, which I tend not to want to do because of the soil compaction. (Jen, Rl)

Land managers should deploy volunteers wherever they will do the least harm, always and everywhere (norm).

(3) Paul talks to the ecologists [to make] sure that what he's doing, what we're doing, is not going to cause more harm ... Barb mentioned how she wanted this whole area mowed out at [natural area]. Okay, now typically we don't start mowing until after August 1st, 'cause that's when the birds are gone. Well this area was so degraded, we didn't think it would be a problem to get in there a little bit before and get a jump start on some of the mowing ... Well, we went in there and mowed it: Oh my God, the shit hit the fan, you know. It was like: "What are you doing?! We had a bird study going on in there!" We were like: I can't believe there was any bird in there because it was just overrun with clover, sweet clover and burdock and all kinds of junk in there. And Paul just figured it was okay to go in there and get a head start. Well, we found out it wasn't ... This was one thing we felt like we were golden. (George, C1-3)

Restorationists must not conduct activities that do ecological harm, always and everywhere, or else risk serious reprimand, or more (rule).

The second institutional statement is a norm because there is an implied pressure felt by Jen to maximize the use of volunteers as well as an obligation to minimize impacts from those volunteers. The third institutional statement was coded as a rule given the obvious trouble that restorationists were in after mowing. In the organization from which this rule was extracted (a co-management case), our qualitative analysis suggests deep-rooted and long-standing distrust, even animosity, among participants. This social atmosphere, in which interpersonal sanctions are not enough, may have contributed to the need for tangible sanctioning through rules. Regardless of the associated sanction, the principle of "do no harm" was present in all of our study organizations.

\section{Respond to sanctions from the land}

We also found, in every organization, people who talked as if the land itself was providing sanctions - in terms of automatic sanctions like increases or decreases 
in biodiversity and health, as well as positive and negative emotional responses felt by people. We coded these statements as norms, because they define the on-the-ground costs or benefits, made evident through emotion, that result from conducting ecological restoration. For example, consider the following interview excerpts and their extracted norms:

(1) When you finally see the fruits of your efforts and you really see an area get turned around. You know, saving it from the brink of extinction and death and all ... rescuing a beautiful sedge meadow valley from buckthorn. When you have your success stories that's always a good thing. [Will, $\mathrm{Cl}-3$ ]

Restorationists may feel a sense of pride when they see the fruits of their labors.

(2) We manage one of the world's largest populations of prairie fringed orchids ... If we don't do it right, the world loses it. There's a purpose and a sense of responsibility to make sure my children and their children see those things. [Erika, M2]

Restorationists may feel guilt if endangered species are lost.

It is clear that these sanctions (positive in excerpt 1, negative in excerpt 2) are strong motivators for restorationists to do the work they do, but the motivation is not described in terms of monetary payoffs, nor is it measured by emotional outcomes induced by coworkers, the public, or any other person. Rather, these sanctions are associated with the overall moral, obligatory, and value-laden undertone expressed in the culture of ecological restoration (Glaser, 2006; Jordan \& Lubick, 2011).

\section{Balance diverse internal stakeholders}

Land managers often describe the need to balance and prioritize different factors (sites, stakeholders, resources, etc.), without defining exactly how much effort should go to one factor or another. For example, consider the following interview excerpt, in which a department manager describes one of the most challenging parts of her job, and the norm we extracted:

(1) On a staff level, it's managing staff expectations. The natural resource people tend to have a very focused, driven, passionate attitude and way they look at things. Versus the planning staff, [who] are much more of a generalist ... So a lot of times, you have the passion of saying, "This has to be like this." And then you have to say, "Wait a minute, no. What are the alternatives?" ... it's hard to manage sometimes, but it probably creates better projects when you have this type of a process. (Ellen, M2) 
Department manager should balance the needs of multiple internal groups, always and everywhere (norm).

Here, the manager is aware of and sympathetic to the multiple perceptions and understandings that those involved with restoration may have. But even more broadly, an organization may need to balance multiple organizational goals. For example, consider the following excerpts and their extracted norms:

(2) ... this being our main education site, we went up against a lot of education programs going on here [so] we can't be aggressively doing land management techniques... So that has, at times, stifled us in what we wanted to do because we have to find balance. (Sam, M4)

Organization may allow education to trump land management at [this particular natural area] (norm).

(3) ... all the time that I've been working here, I've tried to use native, local genotype to restore. Well, this project came on board, so all the seed that I'm collecting this year, most of it is going to this project ... if I use seed there and I don't have it for here [the natural area], then they buy seed. And it usually comes from 150 miles away or further.

Interviewer: So that's defeating your purpose.

Jen: Right. ... it creates a lot of stress for me. Because I'm trying to collect as much native, local genotype as I can here. And I can't collect it all. So they're buying in part of it. Which - that's just the way it has to be. (Jen, R1)

Manager must balance local seed needs in natural areas with local seed needs in special project areas (and so occasionally purchases seed) (norm).

From the second excerpt, we glean how the organization faces the sometime frustrating challenge of negotiating multiple organizational goals-land management, ecological restoration, and education. From the third excerpt we understand that while balancing goals may result in Jen feeling guilt for not sticking to her own restoration philosophy of using only local seed in all areas, she may feel less guilt for having attempted to put at least some local seed in the project area. Further, there may be a larger organizational emotional sanction if Jen does not cooperate in the management of multiple sections for multiple reasons. That is, others in the organization want to see the special project come to fruition, and they rely on Jen for management assistance. 


\section{Balance diverse external factors}

Beyond the perceptions of restorationists themselves and the goals of an organization, there is awareness that the public has diverse interests in natural areas as well. Consider the following interview excerpts in which managers discuss the need to consider non-ecological factors, and their extracted institutional statements:

(1) So what about public perception? That's worth something. It's not just about ecology; it's about beautification, public perception, getting volunteers committed to sites all over [the region]. (Larry, C1-3)

Organization considers science, ecology, neighborhoods, people's interests, and aesthetics in decisions, always and everywhere (strategy).

(2) Even when we do the resource management work, we have to talk about the other public uses ... When there's skiable snow [at a site], you can't drive your machinery or your trucks down the limestone trail because that would conflict with people utilizing the trail. So, we always kind of had to work around things like that. (Ron, M1)

Organization must consider and balance restoration work with public desire for recreation (norm).

Like the rule we describe for the "do no harm" principle above, for the second excerpt we have evidence from additional qualitative analysis to suggest a long-standing issue with public access, which may contribute to the obligatory (although not mandatory) nature of this institutional statement. Both institutional statements describe a recognition of multiple public uses of natural areas (passive aesthetics, active recreation). Although the types and extent of public use vary across sites, we found this recognition in every organization.

\section{Discussion}

One finding of this research is that rules, norms, and strategies can aggregate together to suggest a common principle. The principles we presented above are overwhelmingly composed of strategies and norms. We think this makes sense, for several reasons. Ecological restoration is a fairly new practice; as such, there is still a lot of trial and error and a need for creativity and flexibility. Science has yet to develop a baseline of information needed to construct, and enforce, many restoration rules. In fact, recent legislative action (i.e., the creation of formal rules) concerning restoration in Brazil has drawn criticism, in part because of the potential for rules to force a "one-size-fits-all" approach and to deny the possibility for on-the-ground experimentation (Aronson, 2010; Durigan et al., 2010). Our work indicates the significance of strategies, and especially norms, 
in shaping behavior and decisions in ecological restoration. Thus, our work and results open the door to additional institutional analyses in other contexts. We expect that these other institutional statements would dominate in other land management situations, too, when the application of IAD and ADICO turns from its current focus on formal policy documents and an emphasis on formal rules to the full set of potential institutional statements.

One advantage of strategies is that they are most readily changed (e.g., there is no formal rule-changing mechanism that must take place) and therefore they are more readily adaptable to new scientific information. As the science and practice of ecological restoration advances (setting the stage for creating more rules to guide restoration activities), it is likely that strategies will remain an important institutional type, because of the need to be adaptive and flexible in a dynamic, and at times uncertain, social-ecological system (Armitage et al., 2009; Aronson et al., 2010; Murray \& Marmorek, 2003; Pahl-Wostl et al., 2007). In fact, Gobster (2010) argues that the viability of ecological restoration as a practice, especially in urban areas, depends not only on ecological outcomes but also on how socially successful restoration projects are. The organizations conducting ecological restoration in Chicago Wilderness strive to recognize multiple and diverse stakeholders within, as well as external to, the restoration community. Therefore, while recognizing the importance of the Society for Ecological Restoration's restoration goals of viable structure, function, and stability, they also recognize the importance of including social values in their restoration goals (Aronson et al., 2010; Hallett et al., 2013).

The principles we found are broad, philosophical guidelines, often rooted in a deep understanding of the ecological landscape within which the restorationist is working. For example, knowing how many cherry trees is "too many," how much seed is "sufficient," or when oak "dominance" has been achieved are understandings that are learned over time and with experience deepening a restorationist's understanding of the landscape in which they are working. This supports Simpson's (2009, p. 116) suggestion that “[o]ur generalized management model of how to restore an oak savanna cannot tell us how to restore this oak savanna." Institutional statements that aggregate to principles such as "listen to the land," "do no harm," and "follow-up" reflect a direct and individual relationship with the land, through which management decisions are made. These institutional statements suggest that observation and interpretation are fundamental management tools and the freedom to change perceptions and subsequent decisions is permissible; that is, restorationists engage in what Berkes et al. (2000) call a qualitative approach to adaptive management.

Nonetheless, principles like "listen to the land" beg the question of what to do if multiple people "listen" and hear different things. This is handled in different ways across the organizations we investigated, but respected individuals can 
play a key role in such situations. In some organizations, these individuals are strong leaders, even referred to as benign dictators. In others, individuals have been brought in to the organization specifically to coordinate decision-making in the face of divergent opinions (Zellner et al., 2014). We found these individuals to play a critical role in restoration decision-making since often when there is disagreement, there is no established basis in the scientific literature on which to base decisions (e.g., regarding seeding practices).

That Chicago Wilderness restorationists feel sanctions from the land may indicate a collective cultural ethos and place-based ecological knowledge, that is, a traditional ecological knowledge frequently ascribed to indigenous societies (Long et al., 2003; Plaganyi et al., 2013). Arguably, the institutional statements and the principles they collectively describe highlight the critical connection with and responsibility toward the land, and constitute a nascent form of traditional ecological knowledge. Berkes et al. (2000, p. 1252) argue that it matters less whether practices are traditional or contemporary, but rather that local knowledge exists that "helps monitor, interpret, and respond to dynamic changes in ecosystems and the resources and services that they generate." That these principles are shared across the Chicago Wilderness restoration community suggests a shared collective understanding exists, one capable of igniting cooperation toward a common regional restoration goal.

Finally, one might ask if we needed to conduct the painstaking analysis of extracting each and every rule, norm, and strategy. Might we have found the same information using a more traditional thematic analysis? Yes, and no. The principles identified above could have been identified through our qualitative analysis of the interview data. But understanding the principles in the context of the growing literature on common-pool resources through the lens of the IAD framework and its focus on sanctions could not have been done without extracting the institutional statements. For example, the principle that restorationists use qualitative rather than quantitative measures is distinctly different from extractive common-pool resource situations reported in the literature to date - although we suspect that some of these principles will be found to be at play in extractive situations as well. Also, the prevalence and usefulness (given their ability to change more easily than norms or rules) of strategies would not have been determined without ADICO. Lastly, the concept that sanctions may come from a source other than other people is another significant departure from the existing literature - and one rooted in norms rather than rules. Again, we expect to find these meaningful but non-human sanctions in extractive common-pool resource situations as well, but that is for future research and study. 


\section{Conclusion}

From our analysis of the rules, norms, and strategies found in diverse organizations engaging in ecological restoration in the Chicago Wilderness region, we conclude that a set of philosophical, yet practical, principles guide the practice of ecological restoration. Avoiding harm, listening to the land, practicing follow-up actions, and taking a qualitative approach to actions and outcomes characterize these organizations' restoration approaches. Importantly, all organizations are also guided by basic principles of social collaborationboth internally and externally. Since all organizations, regardless of management style, expressed these principles, we can view them together as a regional system of collective action that is beneficial for the larger good. In the metropolitan region of Chicago Wilderness, this shared understanding represents a strength of the alliance and, just as IUCN suggests, Chicago Wilderness is a model for other conservation efforts (Mackey et al., 2008).

In contrast to previous studies of institutional statements, our work suggests that norms and strategies are just as important, if not more so, than rules in the non-extractive, value-adding context of urban ecological restoration. Norms and strategies form the collective ethos of Chicago Wilderness restorationists, and are whence collaborative and adaptive management can thrive. Continued recognition of the importance of individual experience on and with the land is vital, as such experiences can subsequently create shared understandings of responsibility for and deep knowledge about the land, which in turn may create more resilient and sustainable landscapes that support both people and biodiversity.

\section{References}

Armitage, D. R., Plummer, R., Berkes, F., Arthur, R. I., Charles, A. T., DavidsonHunt, I. J., ... Wollenberg, E. K. (2009). Adaptive co-management for socialecological complexity. Frontiers in Ecology and the Environment, 7, 95-102. doi: 10.1890/070089

Aronson, J. (2010). What can and should be legalized in ecological restoration? Revista Árvore, 34(3), 451-454.

Aronson, J., Blignaut, J. N., Milton, S. J., le Maitre, D., Esler, K., Limouzin, A., ... Lederer, N. (2010). Are socioeconomic benefits of restoration adequately quantified? A meta-analysis of recent papers (2000-2008) in Restoration Ecology and 12 other scientific journals. Restoration Ecology, 18, 143-154. 
Basurto, X., Kingsley, G., McQueen, K., Smith, M., \& Weible, C. M. (2010). A systematic approach to institutional analysis: Applying Crawford and Ostrom's grammar. Political Research Quarterly, 63(3), 523-537.

Berkes, F., Colding, J., \& Folke, C. (2000). Rediscovery of traditional ecological knowledge as adaptive management. Ecological Applications, 10(5), 12511262.

Chhatre, A., \& Agrawal, A. (2008). Forest commons and local enforcement. Proceedings of the National Academy of Sciences, 105(36), 13286-13291.

Coleman, E., \& Steed, B. (2009). Monitoring and sanctioning in the commons: An application to forestry. Ecological Economics, 68, 2106-2113.

Crane, P., Heneghan, L., Muraski-Stotz, F., Pruett-Jones, M., Ross, L., Wali, A., \& Westphal, L. (2014). Chicago Wilderness: Integrating biological and social diversity in the urban garden. In S. B. Hecht, K. D. Morrison \& C. Padoch (Eds.), The social lives of forests (pp. 362-368). Chicago, IL: University of Chicago Press.

Crawford, S., \& Ostrom, E. (1995). A grammar of institutions. American Political Science Review, 89(3), 582-600.

Crawford, S., \& Ostrom, E. (2005). A grammar of institutions. In E. Ostrom (Ed.), Understanding institutional diversity (pp. 137-174). Princeton, NJ: Princeton University Press.

CRBC (Chicago Region Biodiversity Council). (1999). Biodiversity recovery plan. Chicago, IL: CRBC.

Durigan, G., Lex Engel, V., Torezan, J. M., Galvão de Melo, A. C., Mendes Marques, M. C., Martins, S. V., ... Scarano, F. R. (2010). Legal rules for ecological restoration: An additional barrier to hinder the success of initiatives? Revista Árvore, 34(3), 471-485.

Ehrenfeld, J. G. (2000). Defining the limits of restoration: The need for realistic goals. Restoration Ecology, 8(1), 2-9.

Fleischman, F. D., Boenning, K., Garcia-Lopez, G. A., Mincey, S., Schmitt-Harsh, M., Daedlow, K., ... Ostrom, E. (2010). Disturbance, response, and persistence in self-organized forested communities: Analysis of robustness and resilience in five communities in Southern Indiana. Ecology and Society, 15(4), 21.

Gibson, C. C., \& Koontz, T. (1998). When "community" is not enough: Institutions and values in community-based forest management in southern Indiana. Human Ecology, 26(4), 621-647. 
Gibson, C. C., MacKean, M. A., \& Ostrom, E. (Eds.). (2000). People and forests: Communities, institutions, and governance. The MIT Press.

Gibson, C. C., Williams, J. T., \& Ostrom, E. (2005). Local enforcement and better forests. World Development, 33(2), 273-284.

Glaser, M. (2006). The social dimension in ecosystem management: Strengths and weaknesses of human-nature mind maps. Human Ecology Review, 13(2), 122.

Gobster, P. (2010). Introduction: Urban ecological restoration. Nature and Culture, 5(3), 227-230.

Gobster, P., \& Hull, B. (Eds.). (2000). Restoring nature: Perspectives from the social sciences and humanities. Washington, DC: Island Press.

Hallett, L., Diver, M., Eitzel, S., Olson, J. J., Ramage, B. S., Sardinas, H., ... Suding, K. N. (2013). Do we practice what we preach? Goal setting for ecological restoration. Restoration Ecology, 21(3), 312-319.

Heneghan, L., Mulvaney, C., Ross, K., Umek, L., Watkins, C., Westphal, L. M., \& Wise, D. H. (2012). Lessons learned from Chicago Wilderness-Implementing and sustaining conservation management in an urban setting. Diversity, 4(1), 74-93.

Higgs, E. (2005). The two-culture problem: Ecological restoration and the integration of knowledge. Restoration Ecology, 13(1), 159-164.

Hobbs, R. J. (2007). Setting effective and realistic restoration goals: Key directions for research. Restoration Ecology, 15(2), 354-357.

Imperial, M. (1999). Institutional analysis and ecosystem-based management: The institutional analysis and development framework. Environmental Management, 24(4), 449-465.

Jordan, W. R., \& Lubick, G. M. (2011). Making nature whole: A history of ecological restoration. Washington, DC: Island Press.

Knoot, T. G., Schulte, L. A., Tyndall, J. C., \& Palik, B. J. (2010). The state of the system and steps toward resilience of disturbance-dependent oak forests. Ecology and Society, 15(4), 5. Retrieved from http://www.ecologyandsociety. org/vol15/iss4/art5/

Long, J., Tecle, A., \& Burnette, B. (2003). Cultural foundations for ecological restoration on the White Mountain Apache Reservation. Conservation Ecology, 8(1), 4. Retrieved from http://www.ecologyandsociety.org/vol8/ issl/art4/ 
Mackey, B., Kintzele, K., Aftandilian, D., Engel, R. ,\& Heltne, P. (2008). Keeping nature alive: Toward a code of ethics for biodiversity conservation (Biosphere Ethics Project Paper No. 2). Gland, Switzerland \& Bonn, Germany: IUCN.

Madrigal-Ballestero, R., Schlüter, A., \& Lopez, M.C. (2013). What makes them follow the rules? Empirical evidence from turtle egg harvesters in Costa Rica. Marine Policy, 37, 270-277.

Manuel-Navarrete, D., Kay, J. J., \& Dolderman, D. (2004). Ecological integrity discourses: Linking ecology with cultural transformation. Human Ecology Review, 11(3), 215-229.

McGinnis, M. D. (2011). An introduction to IAD and the language of the Ostrom workshop: A simple guide to a complex framework for the analysis of institutions and their development. Policy Studies Journal, 39(1), 169-183.

Mincey, S. K., Hutten, M., Fischer, B. C., Evans, T. P., Stewart, S. I., \& Vogt, J. M. (2013). Structuring institutional analysis for urban ecosystems: A key to sustainable urban forest management. Urban Ecosystems. doi: 10.1007/ s11252-013-0286-3

Murray, C., \& Marmorek, D. (2003). Adaptive management and ecological restoration. In P. Friederici (Ed.), Ecological restoration of southwestern ponderosa pine forests (pp. 417-428). Washington, DC: Island Press.

Ostrom, E. (1990). Governing the commons: The evolution of institutions for collective action. New York: Cambridge University Press.

Ostrom, E. (2005). Understanding institutional diversity. Princeton, NJ: Princeton University Press.

Ostrom, E. (2007). A diagnostic approach for going beyond panaceas. Proceedings of the National Academy of Sciences, 104(39), 15181-15187.

Ostrom, E. (2011). Background on the institutional analysis and development framework. Policy Studies Journal, 39(1), 7-27.

Pahl-Wostl, C. (2006). The importance of social learning in restoring the multifunctionality of rivers and floodplains. Ecology and Society, 11(1), 10. Retrieved from http://www.ecologyandsociety.org/vol11/iss1/art10/

Pahl-Wostl, C., Sendzimir, J., Jeffrey, P., Aerts, J., Berkamp, G., \& Cross, K. (2007). Managing change toward adaptive water management through social learning. Ecology and Society, 12(2), 30. Retrieved from http://www. ecologyandsociety.org/vol12/iss2/art30/ 
Plaganyi, E. E., van Putten, I., Hutton, T., Deng, R. A., Dennis, D., Pascoe, S., ... Campbell, R.A. (2013). Integrating indigenous livelihood and lifestyle objectives in managing a natural resource. Proceedings of the National Academy of Sciences, 110(9), 3639-3644.

Schlüter, A., \& Theesfeld, I. (2010). The grammar of institutions: The challenge of distinguishing between strategies, norms, and rules. Rationality and Society, 22(4), 445-475.

SER (Society for Ecological Restoration). (2004). International primer on ecological restoration. Tucson, AZ: Science \& Policy Working Group, SER.

Siddiki, S., Weible, C. M., Basurto, X., \& Calanni, J. (2011). Dissecting policy designs: An application of the institutional grammar tool. Policy Studies Journal, 39(1), 79-103.

Simpson, T. (2009). A science of land individuals. Ecological Restoration, 27(2), 115-121.

Smith, L. (2013). Geographies of environmental restoration: A human geography critique of restored nature. Transactions of the Institute of British Geographers, 38, 354-358.

Watkins, C., Massey, D., Brooks, J., Ross, K., \& Zellner, M. L. (2013). Understanding the mechanisms of collective decision making in ecological restoration: An agent-based model of actors and organizations. Ecology and Society, 18(2), 32. doi: 10.5751/ES-05497-180232

Westphal, L. M., Watkins, C., Gobster, P. H., Heneghan, L., Ross, K., Ross, L., ... Zellner, M. (2014). Social science methods used in the RESTORE project (General Technical Report NRS-138). Newtown Square, PA: United States Department of Agriculture, Forest Service, Northern Research Station. Retrieved from http://www.fs.fed.us/nrs/pubs/gtr/gtr_nrs138.pdf

Zellner, M., Watkins, C., Massey, D., Westphal, L., Brooks, J., \& Ross, K. (2014). Advancing collective decision-making theory with integrated agentbased modeling and ethnographic data analysis: An example in ecological restoration. Journal of Artificial Societies and Social Simulation, 17(4), 11. Retrieved from http://jasss.soc.surrey.ac.uk/17/4/11.html 
This text taken from Human Ecology Review Volume 21, Number 1, 2015, published 2015 by ANU Press, The Australian National University, Canberra, Australia. 